中の酸素の影響で然燒速度が増大しているときには， それにともなった反庅帯の温度上暴がみとめられる が，この然㜔速度と反応带の温度の相関関係からプロ パンの然焼反応にお汁る活性化エネルギの值を推定 してみた。

(1) 昭 35-4-1 第 37 期通常総会講演会において講演, 原稿受付 昭 36-1-24, 本論交は馀文集 180 号に揭載の予定. (2) 正員, 東京大 学工学部. (3) 東京大学工学部.

\subsubsection{1}

$$
\begin{aligned}
& \text { ホイト・シュナイダ・プロペラ } \\
& \text { に関する一考察 }
\end{aligned}
$$

（続報 1 ；二次元無限翼数を仮定せる場 合のプロペラ円周上における誘起速度分 布の近似語算)

$$
\text { 安藤 常世 }{ }^{(2)}
$$

前報において通常の翼枝摇動機構をもつホイト・シ ュナイダ・プロペラの作用につき二次元準静的状態を 仮定して解析を行なったのに弱続きここで得られた 翼枝束縛うずの大きさの変化をそのままに利用し， プロペラ後流内に残留分布する自由うずが性能に及注 す影響と, 翼枝相互間の干㴹の状態とをプロペラ円周 上に誘起される速度の形で求めようと試みた。取扱い を容易とするために無限翼数の仮定をおき,流れ場(後 流中）に存在する自由うずの分布を局部的に平均化さ れた面分布，翼枝束緟うずをおなじくプロペラ円周に 沿う連続な線分布と考えた。また自由うずは一様流れ とおなじ速度で相対的な分布状態を変えずに移動する ものとした。このような仮定により近似的ではあるが 簡潔吕う統一的な形式で対象とする量の算式が与えら れた。

(1) 昭 33-10-27 菓京秋期講演大会にわいて講演, 原稿受付 昭 35 -11-30, 本論文は諭文集 180 号偈載の予定.（2）正員, 慶応義塾 大学工学部.

\subsubsection{2}

\section{內管が回転する二重管内の流動抵抗 (1)}

山田 豊 ${ }^{(2)}$

本報告は内管が回転する同心二重管内を流れる水の 流動抵抗損失に関する実騃結果を述べたもので, 従来 の研究と比較してレイノルズ数およびすきまの值をよ り広範国に变化させて，流動抵抗の一般的性質を明ら かにした。つぎに流動抵抗を理諭的に求めて実験結果 と比較し，さらに流れの安定について述べた。おもな 結果はつぎのとおりである。

1) $R_{\omega}>10000$ では流勒抵抗係数 $\lambda$ はs $/ r_{1}$ にほとん ぞ関せず,理諭值 $\lambda=0.26 R_{e}^{-0.24}\left\{1+\left(\frac{7}{8}\right)^{2}\left(\frac{R_{\omega}}{2 R_{e}}\right)^{2}\right\}^{0.38}$ とよく一致する。ここに $R_{e}=v_{m} s / \nu, R_{\omega}=u_{1} s / \nu, v_{m}$ は 軸方向の平均流速， $u_{1}$ は内管周速， $s$ はすきま， $\nu$ は 動粘性係数である.2) 層流では $R_{\omega}$ がある值 $\left(R_{\omega c}\right)$ に達するまでは $\lambda$ は少しも変化しないが， $R_{\omega c}$ 以上 になると入は急に増加する. また臨界テーラ数 $R_{\omega C}$ $\left(s / r_{1}\right)^{1 / 2}$ はs $s / r_{1}$ の大きい任ど大きく, $R_{e}$ が約 600 まで は $R_{e}$ の大きい任大きい，3） $R_{e}, R_{\omega}$ がともに小さ い場合には， $R_{\omega}$ の大きいはうが入の值が小さくなる ことがある. また．は内管が回転している時のほう が静止二重管の層流の值より小さくなることがある。 したがって $R_{e}$ のきわめて小さい場合には入の测定か
ら $R_{\omega c}$ を求めることはできない。

(1) 昭 33-4-1 第 35 期通常総会講演会において講演, 原稿受付 昭 35-5-18,本論交は諭交集 180 号化掲載の予定。（2）正員，名古屋 大学工学部.

\subsubsection{3: 621.43 .038 .771}

\section{内燃機関用サイクロン形空気清 浄器の性能 (1)}

山内 博 ${ }^{(2)}$ ，小林恒夫 ${ }^{(3)}$

単シリンダ内燃機関につけたサイクロン形空気清净 器の集じん効率と，その場合の機関の体積効率とをモ 一タリング試験により測定した。その結果を送風機試 験結果と比較した．紙フィルタについても同様の試験 を行なってその結果を比較し，つぎのごとき結果が得 られた. 1) 脈動気流中での空気清净器の最良集じん 効宰値は定常流中のそれより常に劣る。2)送風機試 験によれば，供試機関の吸気量の範囲では，サイクロ ンの集じん効率は紙フィルタのそれより常に低かっ た。しかし機関試験によれば，高速回転時にはサイク ロンのほうが効率がよかった．したがって機関回転速 度の変動による集じん效率の変動は, 紙フィル夕に比 ベてサイクロンは著しく少なかった，3）体積効率は サイクロン管の動的影響を受けて，流動抵抗の少ない サイクロンでは，望んぜん空気清净器をつけない時よ り，数\%よい最良体積效率值を得た。

(1) 昭 34-5-29 新潟地方講演会において諢演,原稿受付 昭 34-5-29, 本論交は諭交集 180 号に钽載の予定. (2),(3) 正員, 大陙府立大学 工学部.

\section{$621.515-154: 533.691$}

\section{ねじりの無い静斑を持つ軸流圧 縮機の実験(1)}

$$
\text { 白戸 健 }{ }^{(2)} \text {, 山根 猛 }{ }^{(3)}
$$

軸流圧縮機にるじりのない静翼を用いることにより 製作を簡単にすることができる、設計の際に内部の流 れの半径方向の平衡を考慮すれば效率も良好であり， 一種の半うず巻形であるから，自由うず形よりはマッ 八数の制限が少ないので圧力比を大きくとり得ること 夯知られている。この形式の軸流玨䈹機の単段低速試 験機を製作し，内部の流れの則定および全体の特性の 浿定を行なった。実験の結果全体として設計に良く合 致した性能ふ得られ，内部の流れの状態もほほ設計に 近い状態になっていることがわかった。ただし実験装 置の関係で効率の正確な絶対值を得ることはできなか った.

(1) 昭 35-10-14 第 38 期東京秋期講演大会において論交請演として 講演, 原稿受付 昭 35-7-18, 本諭文は諭交集 180 号に掲載の予定. （2）正員，三并造㖣会社玉野造船所（3）准員，三井造船会社玉野 造船所.

\subsubsection{1}

$$
\begin{aligned}
& \text { ホイト・シュナイダ・プロペラ } \\
& \text { に関するー考察(1) }
\end{aligned}
$$$$
\left.\begin{array}{l}
\text { (続報 } 2, \text { 後流の非一様加速を } \\
\text { 考慮した場合の推進性能 }
\end{array}\right)
$$

$$
\text { 安 藤 常世(2) }
$$

前 2 報で得られた結果を利用してホイト・シェナイ ダ・プロペラの推進性能を，線形的な考え方によって 㻎論的に求めた。态実比が微小である場合に対しては， 